\title{
Stimulation of inorganic-phosphate incorporation into phosphatidylinositol in rat thoracic aorta mediated through $\mathrm{V}_{1}$-vasopressin receptors
}

\author{
Amrit P. S. TAKHAR and Christopher J. KIRK* \\ Department of Biochemistry, University of Birmingham, P.O. Box 363, Birmingham B15 2TT, U.K.
}

(Received 21 July 1980/Accepted 4 September 1980)

\begin{abstract}
Vasopressin stimulates the incorporation of $\left[{ }^{32} \mathrm{P}\right] \mathrm{P}_{1}$ into phosphatidylinositol but not into other phospholipids in rat thoracic aorta strips. The relative abilities of three vasopressin analogues to stimulate phosphatidylinositol labelling in rat aorta are similar to their relative pressor potencies in vivo and to their relative potencies in stimulating the metabolism of rat hepatocytes, but very different from their relative antidiuretic potencies. The vasopressor antagonist [1- $(\beta$-mercapto- $\beta, \beta$-cyclopentamethylenepropionic acid),8-arginine]vasopressin competitively inhibits [ $\mathrm{Arg}^{8}$ ]vasopressin-stimulated phosphatidylinositol labelling in rat aorta with a $\mathrm{pA}_{2}$ of 8.1. It is concluded that the $\mathrm{Ca}^{2+}$-mobilizing vasopressin receptors $\left(\mathrm{V}_{1}\right.$-receptors $)$ of the rat aorta stimulate phosphatidylinositol metabolism, probably by enhancing phosphatidylinositol breakdown.
\end{abstract}

Vasopressin, like some other hormones and neurotransmitters (e.g. catecholamines and histamine), can influence target tissues through more than one route of receptor-response coupling. It increases the permeability of the collecting ducts of mammalian kidney by activating adenylate cyclase (Nakahara et al., 1978), but it activates glycogen phosphorylase and gluconeogenesis in liver without increasing the hepatic concentration of cyclic AMP (Hems \& Whitton, 1973; Hems et al., 1976; Kirk \& Hems, 1974). There is considerable evidence that the hepatic effects of vasopressin are mediated through an increase in the concentration of $\mathrm{Ca}^{2+}$ in the cytosol (Stubbs et al., 1976; Keppens et al., 1977; Blackmore et al., 1978; Chen et al., 1978; Garrison et al., 1979). In addition, vasopressin is a potent stimulus for the contraction of vascular smooth muscle. This response, like hepatic glycogenolysis, is abolished if the muscle is deprived of extracellular $\mathrm{Ca}^{2+}$ (Altura \& Altura, 1976, 1977), suggesting that a rise in cytosolic $\mathrm{Ca}^{2+}$ concentration is also the initiator of vasopressin-induced vascular contraction.

More recently there have been two further advances in our knowledge of hepatic vasopressin responses. First, it was realized that hepatic vasopressin receptors, like many other cell-surface receptors that use $\mathrm{Ca}^{2+}$ as their 'second messenger' (Jones et al., 1979; Michell, 1979) stimulate the

\footnotetext{
* To whom reprint requests should be sent.
}

breakdown of phosphatidylinositol, a quantitatively minor membrane phospholipid. We have suggested that this reaction might be essential for the mobilization of $\mathrm{Ca}^{2+}$ in the cytosol by hepatic vasopressin receptors (Kirk et al., 1977, 1978, 1979, 1980, 1981; Billah \& Michell, 1978, 1979; Michell et al., 1979). Secondly, studies with a variety of vasopressin analogues showed that the ligand selectivity of hepatic vasopressin receptors is very similar to the ligand selectivity of the vascular vasopressin receptors that mediate the pressor response to vasopressin in vivo (Kirk et al., 1979, 1981; Michell et al., 1979; Keppens \& De Wulf, 1979). These studies have led us to suggest that the $\mathrm{Ca}^{2+}$ mobilizing vasopressin receptors of the liver and vasculature $\left(V_{1}\right.$-receptors; Michell et al., 1979) might share a mechanism of action in which the breakdown of phosphatidylinositol is an essential step). The experiments described in the present paper were undertaken to test the essential prediction (Michell et al., 1977, 1979) that vasopressin should stimulate phosphatidylinositol metabolism in those smooth muscles in which it evokes contraction, and to examine the nature of the receptors that mediate any such response.

\section{Materials and methods}

\section{Preparation and incubation of aortic strips}

Male Wistar rats $(250-350 \mathrm{~g})$ were killed by exsanguination from the abdominal aorta under 
diethyl ether anaesthesia. Their thoracic aortae were collected into an incubation medium consisting of bicarbonate-buffered physiological saline (Krebs \& Henseleit, 1932), gassed with $\mathrm{O}_{2} / \mathrm{CO}_{2}(19: 1)$ and containing $10 \mathrm{~mm}$-glucose. The aortae were dissected free of connective tissue and fat, and the aortic arch was routinely discarded since preliminary experiments indicated that it exhibited rather variable sensitivity to vasopressin as compared with the thoracic aorta itself. The thoracic aortae were bisected first transversely and then longitudinally such that a single aorta yielded four strips, each of which weighed $5-10 \mathrm{mg}$.

The aortic strips were carefully blotted to remove excess medium, weighed and placed in individual flat-bottomed plastic vials $(1 \mathrm{~cm}$ diameter $)$ containing $0.25 \mathrm{ml}$ of incubation medium. The vials were gassed with $\mathrm{O}_{2} / \mathrm{CO}_{2}(19: 1)$, capped and incubated at $37^{\circ} \mathrm{C}$ for $60 \mathrm{~min}$ in a gently shaking water bath. At the end of this period, hormones were added to the vials together with a further $0.25 \mathrm{ml}$ of incubation medium containing $20 \mu \mathrm{Ci}$ of $\left[{ }^{32} \mathrm{P}\right] \mathrm{P}_{1} / \mathrm{ml}$. The vials were re-gassed, capped and further incubated with gentle shaking for the times indicated in the legends to the Figures. All vials were re-gassed at $30 \mathrm{~min}$ intervals throughout the incubations. It has been reported that the sensitivity of rabbit thoracic aorta to vasopressin diminishes towards the posterior end of the vessel (Altura \& Altura, 1970). Our initial experiments suggested that this was not the case with rat aorta, and aortic strips from different regions of the vessel were distributed randomly amongst the incubation vials in the present study.

\section{Lipid extraction and isolation}

Incubations were terminated with the additions of $1.9 \mathrm{ml}$ of chloroform/methanol $(1: 2, \mathrm{v} / \mathrm{v})$ and the aortae were washed into plastic scintillation vials with a further $1.9 \mathrm{ml}$ of chloroform/methanol $(1: 2, v / v)$. The tissue was homogenized with a topdrive rotary-blade homogenizer at full speed $(14000 \mathrm{rev} . / \mathrm{min})$ for $2 \mathrm{~min}$. The lipid extracts were transferred to glass test-tubes containing $1.25 \mathrm{ml}$ of chloroform and $1.75 \mathrm{ml}$ of $2 \mathrm{M}-\mathrm{KCl}$ and were thoroughly mixed. After gentle centrifugation, the lower chloroform phase was removed by aspiration and the upper phase was washed with a further small portion of chloroform. The chloroform phases were combined, evaporated to dryness under vacuum and the extracted lipids were separated on formaldehyde-treated papers (Kirk et al., 1979).

Spots containing phosphatidylinositol and the other major phospholipids were identified with the aid of pure phospholipid standards, excised and wet-ashed in $\mathrm{HClO}_{4}$ (Jones \& Michell, 1974). In the time-course experiment (Fig. 1), the incorporation of $P_{1}$ into phosphatidylinositol was expressed as ng-atoms incorporated/g of fresh tissue. However, when results from separate experiments were expressed in this way, considerable variability was encountered due to the problem of weighing small quantities of tissue that may carry various amounts of surface water. In subsequent experiments, the incorporation of $\mathbf{P}_{1}$ into phosphatidylinositol has been expressed in terms of the ratio: radioactivity in phosphatidylinositol/radioactivity in other major

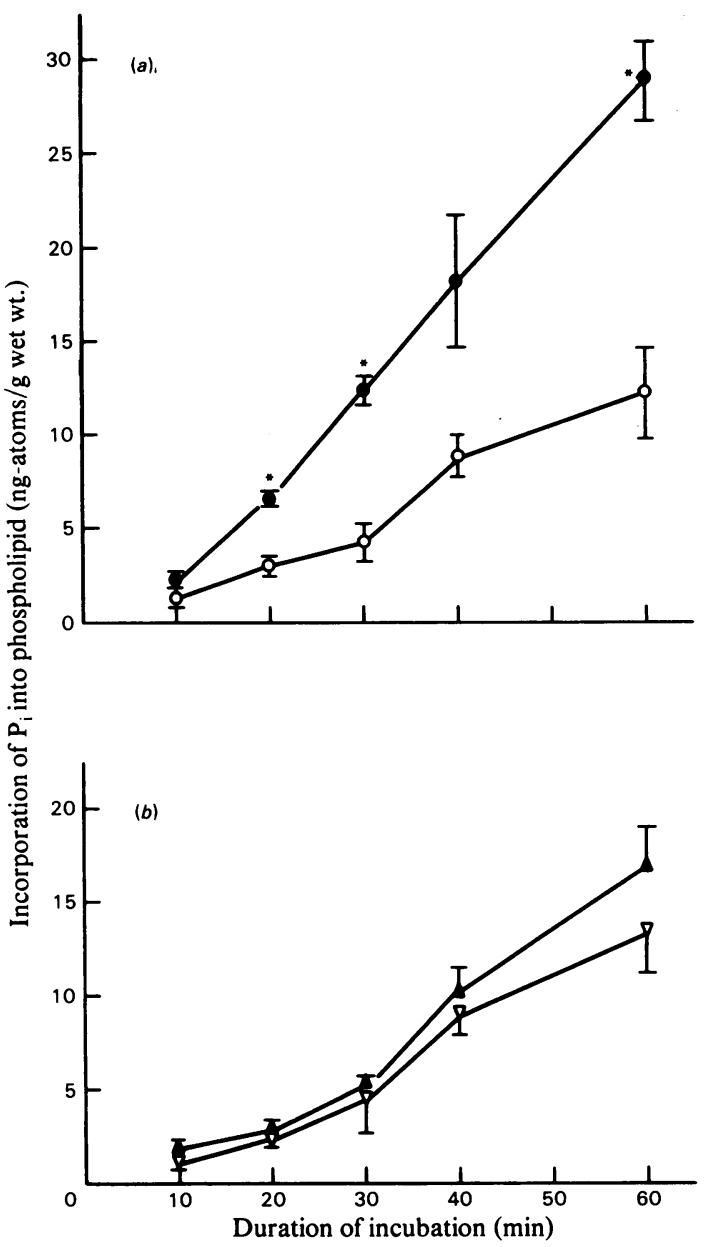

Fig. 1. Influence of vasopressin on the time course of $P_{i}$ incorporation into phospholipids in rat thoracic aorta Aortic segments were incubated with $\left[{ }^{32} \mathrm{P}\right] \mathrm{P}_{1}$ in the presence (closed symbols) or absence (open symbols) of $0.5 \mu \mathrm{M}$-vasopressin for the times indicated. Lipids were extracted and chromatographed as described in the text to yield phosphatidylinositol (Fig. 1a) and a spot containing the other major phospholipids (phosphatidylethanolamine, phosphatidylcholine, phosphatidylserine, sphingomyelin; Fig. 1b). Results are means \pm S.E.M. from aortic segments taken from three separate rats for each point. ${ }^{*} P$ (versus hormone-free controls) $<0.01$. 
phospholipids. This provides a sensitive measure of phosphatidylinositol labelling in conditions where it has been shown that the incorporation of $P_{1}$ into other phospholipids remains unchanged (see Fig. 1 and Jones \& Michell, 1974).

\section{Materials}

[Arg ${ }^{8}$ Vasopressin (grade V1) and phospholipid standards were from Sigma Chemical Co. [ 1 - $(\beta$-Mercapto- $\beta, \beta$-cyclopentamethylenepropionic acid), 8 - arginine $]$ vasopressin ([1 - $\{\alpha$ - (1 - mercaptocyclohexyl)acetic acid \},8-arginine]vasopressin) and $\left[\mathrm{Val}^{4}, \mathrm{Arg}^{8}\right]$ vasopressin were gifts from Professor M. Manning, Medical College of Ohio, Toledo, $\mathrm{OH}$, U.S.A. [D-Arg ${ }^{8}$ ]Vasopressin was a gift from Dr. H. Vilhardt, Ferring Pharmaceuticals, Malmo, Sweden.

\section{Results}

The incorporation of $\mathrm{P}_{1}$ into phosphatidylinositol followed a rising time course over the $60 \mathrm{~min}$ incubation period. At all times tested $\left[\mathrm{Arg}^{8}\right]$ vasopressin $(0.5 \mu \mathrm{M})$ enhanced the incorporation of $P_{1}$ into phosphatidylinositol, but not into other phospholipids (Fig. 1).

The dose-response curves for stimulation of phosphatidylinositol labelling by $\left[\mathrm{Arg}^{8}\right]$ vasopressin, $\left[\mathrm{Val}^{4}, \mathrm{Arg}^{8}\right]$ vasopressin and $\left[\mathrm{D}-\mathrm{Arg}^{8}\right]$ vasopressin are shown in Fig. 2. The latter two analogues exhibited only partial agonist activity with respect to the stimulation of phosphatidylinositol labelling. The relative abilities of these three peptides to promote phosphatidylinositol labelling in aortic strips are compared with their relative pressor, antidiuretic and hepatic potencies in Table 1.

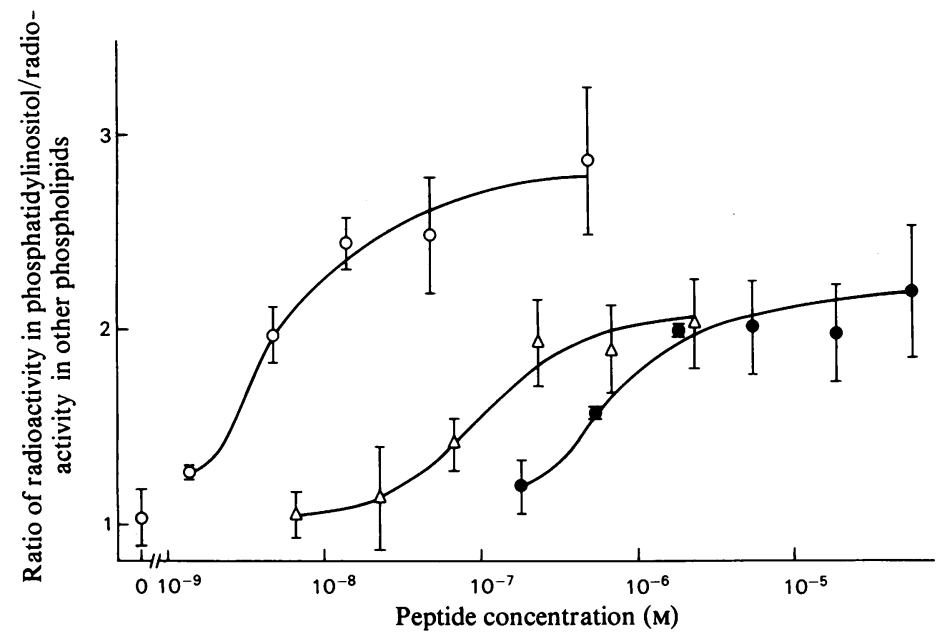

Fig. 2. Concentration dependence of stimulated $P_{i}$ incorporation into phosphatidylinositol in the presence of $\left[\mathrm{Arg}^{8}\right]$ vasopressin, $\left[\mathrm{Val}^{4}, \mathrm{Arg}^{8}\right]$ vasopressin and $\left[\mathrm{D}-\mathrm{Arg}^{8}\right]$ vasopressin in rat thoracic aorta

Aortic segments were incubated for $30 \mathrm{~min}$ with $\left[{ }^{32} \mathrm{P}\right] \mathrm{P}_{1}$, and $\left[\mathrm{Arg}^{8}\right]$ vasopressin $(\mathrm{O}),\left[\mathrm{Val}^{4}, \mathrm{Arg}^{8}\right] \mathrm{vasopressin}(\triangle)$ or $\left[D-\mathrm{Arg}^{8}\right]_{\text {vasopressin }(O)}$ at the concentrations indicated. The incorporation of $\mathrm{P}_{\mathrm{i}}$ into phosphatidylinositol is expressed as the ratio: radioactivity (d.p.m.) in phosphatidylinositol/radioactivity (d.p.m.) in other phospholipids as described in the text. Results are means \pm S.E.M. from aortic segments taken from three to five rats for each point.

Table 1. Influence of vasopressin and related peptides on cellular responses

Results were obtained from Fig. 2 and the references listed. The relative molar activities are compared with $\left[\mathrm{Arg}^{8}\right]$ vasopressin $=1$. References: *Sawyer et al. (1974); †Kirk et al. (1978); †Keppens \& De Wulf (1979).

\begin{tabular}{|c|c|c|c|c|c|}
\hline & \multicolumn{2}{|c|}{ Vascular activity } & \multicolumn{2}{|c|}{ Hepatic activity } & \multirow{2}{*}{$\begin{array}{l}\text { Renal antidiuretic } \\
\text { activity } \\
\text { (in vivo) })^{*}\end{array}$} \\
\hline & $\begin{array}{l}\text { Pressor } \\
\text { (in vivo)* }\end{array}$ & $\begin{array}{l}\text { Phosphatidylinositol } \\
\text { labelling (aortic strips) }\end{array}$ & $\begin{array}{l}\text { Phosphorylase } \\
\text { activation }\end{array}$ & $\begin{array}{l}\text { Phosphatidylinositol } \\
\text { labelling } \dagger\end{array}$ & \\
\hline$\left[\operatorname{Arg}^{8}\right]_{\text {vasopressin }}$ & 1.0 & 1.0 & $1.0 \dagger$ & 1.0 & 1.0 \\
\hline$\left[\mathrm{Val}^{4}, \mathrm{Arg}^{8}\right]$ vasopressin & 0.09 & 0.06 & $0.07 \ddagger$ & - & 2.2 \\
\hline [D-Arg ${ }^{8}$ ]vasopressin & 0.003 & 0.07 & $0.005 t$ & 0.004 & 0.8 \\
\hline
\end{tabular}

Vol. 194 


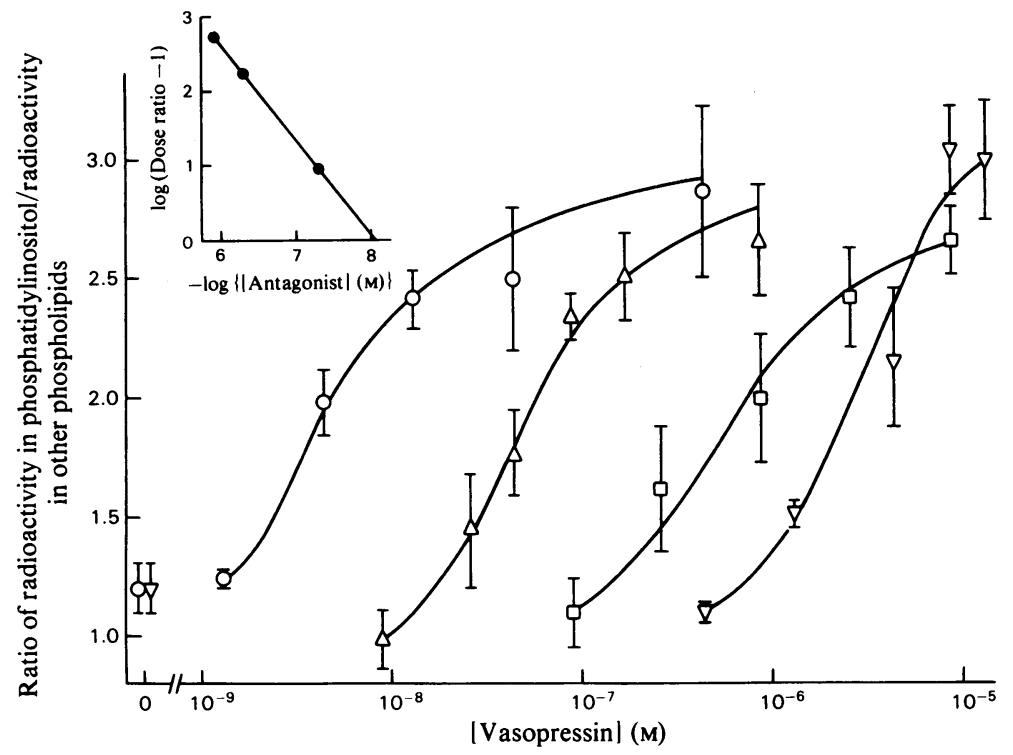

Fig. 3. Inhibition by [1-( $\beta$-mercapto- $\beta, \beta$-cyclopentamethylenepropionic acid $), 8$-arginine]vasopressin of $\left[\right.$ Arg $\left.{ }^{8}\right]$ vasopressininduced phosphatidylinositol labelling in rat thoracic aorta

[1-( $\beta$-Mercapto- $\beta, \beta$-cyclopentamethylene propionic acid),8-arginine]vasopressin was added to vials containing aortic segments $5 \mathrm{~min}$ before the addition of $\left.{ }^{32} \mathrm{P}\right] \mathrm{P}_{1}$ and $\left[\mathrm{Arg}^{8}\right]$ vasopressin to give the following final concentrations: $50 \mathrm{nM}(\triangle), 0.5 \mu \mathrm{M}(\square)$ and $1.5 \mu \mathrm{M}(\nabla)$. Results in the absence of antagonist $(0)$ are taken from Fig. 2. Results are means \pm S.E.M. from aortic segments taken from three to four rats for each point. When replotted by the method of Schild (1947) these results yield a $\mathrm{pA}_{2}$ value for the inhibition of phosphatidylinositol labelling of 8.1 (inset).

The antipressor antagonist $[1-(\beta$-mercapto$\beta, \beta$-cyclopentamethylenepropionic acid),8-arginine]vasopressin competitively inhibited the stimulation of phosphatidylinositol labelling provoked by [ $\left.\mathrm{Arg}^{8}\right]-$ vasopressin (Fig. 3). The $\mathrm{pA}_{2}$ [- $\log$ (antagonist concentration that doubles the concentration of agonist required to evoke a half-maximal response)] for this inhibition was calculated by the method of Schild (1947) and found to be 8.1 (Fig. 3, inset).

\section{Discussion}

Rat aorta is a tissue that supports a rapid rate of $P_{1}$ incorporation into phosphatidylinositol even when unstimulated, with this lipid incorporating about half of the $\left[{ }^{32} \mathrm{P}\right] \mathrm{P}_{1}$ that is found in total aortic lipids. The only other aorta to have been investigated is that from cat, where about one-quarter of the incorporated $\left[{ }^{32} \mathrm{P}\right] \mathrm{P}_{1}$ is found in phosphatidylinositol (Lapetina et al., 1976). By contrast, in unstimulated hepatocytes much less of the $\left[{ }^{32} \mathrm{P}\right] \mathrm{P}_{\mathrm{i}}$ incorporated into lipids (about (12\%) is found in phosphatidylinositol (Kirk et al., 1977). Despite this difference between the unstimulated tissues, the present results show that in aorta, as in hepatocytes, vasopressin stimulates the incorporation of $\left.{ }^{32} \mathrm{P}\right] \mathrm{P}_{\mathbf{i}}$ into phosphatidylinositol, but not into other phospholipids. Lapetina et al. (1976) have previously reported that $\alpha$-adrenergic stimuli selectively enhance phosphatidylinositol labelling in isolated cat aorta. The selective stimulation of $\left.{ }^{32} \mathrm{P}\right] \mathrm{P}_{1}$ incorporation into phosphatidylinositol observed in the present study is similar to that provoked by many other ligands whose influence on their target tissues is mediated by a rise in intracellular $\mathrm{Ca}^{2+}$ concentration (Michell, 1975, 1979). All of the available evidence is consistent with the view that in each of these situations, including the vasopressin-stimulated hepatocyte (Billah \& Michell, 1979; Kirk et al., 1981), the initial event that is stimulated by receptor occupation is phosphatidylinositol breakdown (Michell, 1975; Jones et al., 1979). We would expect that this is also the initiating event in the stimulation of phosphatidylinositol metabolism in rat aorta by vasopressin, but we have thus far been unable to make appropriate measurements with the small amounts of available tissue.

The four vasopressin-like peptides used in the present study were chosen for their qualities as three agonists of widely differing pressor potencies and as a selective inhibitor of the pressor effects of vasopressin. The relative abilities of the three 
agonists to stimulate aortic phosphatidylinositol metabolism were very similar to their relative pressor potencies in vivo (see Fig. 2 and Table 1). Similarly, the potency of [1- $(\beta$-mercapto $-\beta, \beta-$ cyclopentamethylenepropionic acid), 8 - arginine] vasopressin as a competitive inhibitor of vasopressin-stimulated phosphatidylinositol metabolism $\left(\mathrm{pA}_{2}=8.1\right.$; Fig. 3 ) closely matched its potency as a competitive inhibitor of the pressor effect of vasopressin in vivo $\left(\mathrm{pA}_{2}=8.35\right.$; Kruszynski et al., 1980). In the absence of published information on the relative abilities of these four ligands to affect contractility in isolated aorta, these results suggest that the same type of vasopressin receptor is responsible both for stimulating aortic phosphatidylinositol labelling, presumably by stimulation of phosphatidylinositol breakdown, and for initiating the contraction of arterial smooth muscle that contributes to a vasopressin-induced increase in blood pressure in vivo.

The concentrations of $\left[\mathrm{Arg}^{8}\right]$ vasopressin and [D-Arg ${ }^{8}$ ]vasopressin that provoked half-maximal phosphatidylinositol labelling in the present study of aorta (5.5 $\mathrm{nM}$ and $790 \mathrm{nM}$ respectively) were very similar to the concentrations that provoked halfmaximal labelling in hepatocytes $(2.7 \mathrm{~nm}$ and $710 \mathrm{nM}$ respectively; Kirk et al., 1979). Furthermore, [D-Arg ${ }^{8}$ ]vasopressin was a partial agonist that showed about the same efficacy in both systems, and the vasopressin antagonist [1- $(\beta$-mercapto$\beta, \beta$-cyclopentamethylenepropionic acid),8-arginine]vasopressin showed approximately similar affinities in competitively inhibiting the phosphatidylinositol labelling responses of the two tissues $\left(\mathrm{pA}_{2}=8.1\right.$ in aorta and 9.0 in hepatocytes; see Kirk et al., 1981). The relative potencies of the chosen agonists as antidiuretic agents are quite different from their relative pressor potencies or their relative abilities to stimulate phosphatidylinositol turnover (Table 1). These observations are therefore in keeping with the suggestion that the hepatic and arterial effects of vasopressin are mediated through receptors that show a variety of marked similarities; they both exhibit similar ligand selectivities, they both stimulate the metabolism of phosphatidylinositol and they both use $\mathrm{Ca}^{2+}$ as their intracellular signal. Mechanistically, these receptors resemble $\alpha_{1}$-adrenergic receptors and $\mathrm{H}_{1}$-histamine receptors, and we therefore suggested (Michell et al., 1979) that they might appropriately be termed $\mathrm{V}_{1}$-receptors, so as to distinguish them from adenyl cyclase-coupled renal receptors that are responsible for inhibiting diuresis $\left(\mathrm{V}_{2}\right.$-receptors).

The present results are also consistent with our previous suggestion (Kirk et al., 1979) that stimulated phosphatidylinositol degradation is a direct consequence of interaction between vasopressin and the $\mathrm{V}_{1}$-receptors, and that it may be intrinsic to the mechanism whereby the hormone mobilizes $\mathrm{Ca}^{2+}$ in the cytosol. It is striking that the concentrations of $\left[\mathrm{Arg}^{8}\right]$ vasopressin necessary to provoke half-maximal contraction of rat thoracic aortic strips (3.5 nM; Altura, 1974), half-maximal phosphatidylinositol labelling in aorta $(5.5 \mathrm{nM})$ and half-maximal phosphatidylinositol breakdown and labelling in liver $(4.7 \mathrm{nM}$ and $2.7 \mathrm{~nm}$ respectively; Kirk et al., 1981) are all very similar. These concentrations are also very similar to the concentration of $\left[\mathrm{Lys}^{8}{ }^{8}\right.$ vasopressin that gives half-maximal occupation of hepatic receptors $(4.9 \mathrm{~nm}$; Cantau et al., 1980). If the stimulation of phosphatidylinositol metabolism in aorta is closely coupled to receptor occupation (as seems to be the case in the liver) then these results suggest that, at least in relation to vasopressin-stimulated contraction, there is no 'receptor reserve' of aortic $\mathrm{V}_{1}$-receptors. This is in contrast with the substantial receptor reserve observed in the activation of hepatic phosphorylase by vasopressin (Kirk et al., 1979). Altura (1974, 1975) has reported that arterioles and muscular venules are much more sensitive to vasopressin than is aorta, and he has suggested that their contraction contributes more to the pressor effect of the hormone than does contraction of the major blood vessels. We would predict that these smaller vessels, which should possess a greater concentration of vasopressin receptors, would exhibit a receptor reserve with respect to vasopressin-induced contraction but not with respect to phosphatidylinositol labelling. Effective concentrations of the hormone should also provoke a greater stimulation of phosphatidylinositol metabolism in these vessels than is observed in aorta.

We thank the M.R.C. for financial support. A. P. S. T. was the recipient of an M.R.C. Intercalated Studentship.

\section{References}

Altura, B. M. (1974) Proc. Soc. Exp. Biol. Med. 146, $1054-1060$

Altura, B. M. (1975) J. Pharmacol. Exp. Ther. 193, 413-423

Altura, B. M. \& Altura, B. T. (1970) Eur. J. Pharmacol. $12,44-52$

Altura, B. M. \& Altura, B. T. (1976) Proc. Soc. Exp. Biol. Med. 151, 752-755

Altura, B. M. \& Altura, B. T. (1977) Fed. Proc. Fed. Am. Soc. Exp. Biol. 36, 1853-1860

Billah, M. M. \& Michell, R. H. (1978) Biochem. Soc. Trans. 6, 1033-1035

Billah, M. M. \& Michell, R. H. (1979) Biochem. J. 182, 661-668

Blackmore, P. F., Brumley, F. T., Marks, J. L. \& Exton, J. H. (1978) J. Biol. Chem. 253, 4851-4858

Cantau, B., Keppens, S., De Wulf, H. \& Jard, S. (1980) $J$. Receptor Res. in the press

Chen, J.-L. J., Babcock, D. F. \& Lardy, H. A. (1978) Proc. Natl. Acad. Sci. U.S.A. 75, 2234-2238 
Garrison, J. C., Borland, M. K., Florio, V. A. \& Twible, D. A. (1979) J. Biol. Chem. 254, 7147-7156

Hems, D. A. \& Whitton, P. D. (1973) Biochem. J. 136, 705-710

Hems, D. A., Rodrigues, L. M. \& Whitton, P. D. (1976) Biochem. J. 160, 367-374

Jones, L. M. \& Michell, R. H. (1974) Biochem. J. 142, 583-590

Jones, L. M., Cockcroft, S. \& Michell, R. H. (1979) Biochem. J. 182, 669-676

Keppens, S. \& De Wulf, H. (1979) Biochim. Biophys. Acta 588, 63-69

Keppens, S., Vandenheede, J. R. \& De Wulf, H. (1977) Biochim. Biophys. Acta 496, 448-457

Kirk, C. J. \& Hems, D. A. (1974) FEBS Lett. 47, 128-131

Kirk, C. J., Verrinder, T. R. \& Hems, D. A. (1977) FEBS Lett. 83, 267-271

Kirk, C. J., Verrinder, T. R. \& Hems, D. A. (1978) Biochem. Soc. Trans. 6, 1031-1033

Kirk, C. J., Rodrigues, L. M. \& Hems, D. A. (1979) Biochem.J. 178, 493-496

Kirk, C. J., Billah, M. M., Jones, L. M. \& Michell, R. H. (1980) Horm. Cell Regul. 4, 73-88

Kirk, C. J., Michell, R. H. \& Hems, D. A. (1981) Biochem. J. 194, 155-165
Krebs, H. \& Henseleit, K. (1932) Hoppe-Seyler's Z. Physiol. Chem. 210, 33-36

Kruszynski, M., Lammek, B., Manning, M., Seto, J., Haldar, J. \& Sawyer, W. H. (1980) J. Med. Chem. 23, 364-368

Lapetina, E. G., Briley, P. A. \& De Robertis, E. (1976) Biochim. Biophys. Acta 431, 624-630

Michell, R. H. (1975) Biochim. Biophys. Acta 415, 81-147

Michell, R. H. (1979) Trends Biochem. Sci. 4, 128131

Michell, R. H., Jafferji, S. S. \& Jones, L. M. (1977) in Function and Biosynthesis of Lipids (Bazan, N. G., Bremer, R. R. \& Giusto, N. N., eds.) pp. 447-464, Plenum Press, New York

Michell, R. H., Kirk, C. J. \& Billah, M. M. (1979) Biochem. Soc. Trans. 7, 861-865

Nakahara, T., Terada, S., Pincus, J., Flouret, G. \& Hechter, O. (1978) J. Biol. Chem. 253, 32113218

Sawyer, W. H., Acosta, M., Balaspiri, L., Judd, J. \& Manning, M. (1974) Endocrinology 94, 11061115

Schild, H. O. (1947) Br. J. Pharmacol. 11, 189-206

Stubbs, M., Kirk, C. J. \& Hems, D. A. (1976) FEBS Lett.

69, 199-202 